\title{
Detection of Bovine Herpesvirus 1 from Semen by Real-time PCR to Prevent the Spread of Infectious Bovine Rhinotracheitis Infection
}

\author{
Tri Untari $^{1}$, Yuli Purwandari Kristianingrum ${ }^{2 *}$, and Asmarani Kusumawati ${ }^{3}$ \\ ${ }^{I}$ Department of Microbiology, Faculty of Veterinary Medicine, University of Gadjah Mada, Indonesia \\ ${ }^{2}$ Department of Pathology, Faculty of Veterinary Medicine, University of Gadjah Mada, Indonesia \\ ${ }^{3}$ Department of Reproduction, Faculty of Veterinary Medicine, University of Gadjah Mada, Indonesia \\ *Corresponding author’s Email: yuli_purwandari@mail.ugm.ac.id; (iDORCiD: 0000-0002-0245-7632
}

\begin{abstract}
Infectious Bovine Rhinotracheitis (IBR) can be transmitted by livestock seeds and semen, through the process of artificial insemination. Therefore, it is necessary to detect the presence of the Bovine Herpesvirus 1 (BHV1) in semen through artificial insemination and breeding centers of Indonesia. The current study aimed to detect the presence of the virus in semen as a source of IBR disease transmission in Indonesia. A total of 27 semen samples from artificial insemination and breeding centers (Sembawa, Lembang, Ungaran, and Sleman) in Indonesia have been examined and identified using the real-time PCR (qPCR) technique. The result showed that all samples were negative to BHV1. This indicated that semen from Ungaran, Sembawa, Sleman, and Lembang was safe to be used as a semen source for artificial insemination.
\end{abstract}

Keywords: Artificial insemination, Bovine Herpesvirus 1, Infectious Bovine Rhinotracheitis, Real-time PCR, Semen

\section{INTRODUCTION}

Infectious Bovine Rhinotracheitis (IBR) caused by Bovine Herpesvirus 1 (BHV-1) is one of the strategic infectious animal diseases in Indonesia according to the Decree of the Minister of Agriculture Number 4026/Kpts/OT.140/4/2013 that is intended to control the spread of animal diseases. Data on IBR seroepidemiology in Indonesia have indicated that positive serum results have increased over time (Anonim, 2014). Infectious Bovine Rhinotracheitisdisease causes an abortion rate of about $44.8 \%$ in dairy cattle of Indonesia (Anonim, 2014). Infection of BHV-1 can be transmitted through direct and indirect contact with ocular, nasal, and genital secretions (Silva-Frade et al., 2014) or livestock seeds and semen. The BHV-1 in bulls' semen results in extensive viral dissemination through natural mating or artificial insemination (Raaperi et al., 2014). In Brazil, the detected HPV-1 in bulls' semen of artificial insemination (AI) centers and farms led to a reproductive failure (Oliviera et al., 2011). Based on the pattern of IBR transmission disease through the AI process, it is necessary to trace the presence of the BHV1 virus in bulls' semen produced by and breeding centers. The current study aimed to trace the presence of the virus in bull's semen as a source of IBR disease transmission in several AI and breeding centers of Indonesia, namelySembawa, Lembang, Ungaran, and Sleman, which provide sperm for the AI process. The virus tracking in bulls' semen is one of the efforts to prevent, control, and spread IBR disease in Indonesia.

\section{MATERIALS AND METHODS}

\section{Ethical approval}

Procedures involving animals for this study were approved and conducted according to ethical clearance at the Faculty of Veterinary Medicine, University of Gadjah Mada, Indonesia.

\section{Study design}

The current study was conducted in the Faculty of Veterinary Medicine, University of Gadjah Mada, and Veterinary Center, Special Region of Yogyakarta, Indonesia. A total of 27 semen samples were collectedfrom 4 AI and breeding centers in Indonesia (Sembawa, Lembang, Sleman, and Ungaran). Sample preparation was carried out in Biosafety Cabinet (BSC) level II. Semen samples in viral transport media were centrifuged at $1000 \mathrm{rpm}$ for 10 minutes. The supernatant was collected and was ready for DNA extraction. DNA was extracted with the QIAamp DNA Mini Kit (QIAGEN, Cat. No. 51304) according to the procedure specified by the DNA Extraction Protocol. 
The utilized primers included gB-F: 5'-TGT-GGA-CCT-AAA-CCT-CAC-GGT-3' (position 57499-57519 GenBank®, accession AJ004801), gB-R: 5'-GTA-GTC-GAG-CAG- ACC-CGT-GTC-3' (position 57595-57575 GenBank®, accession AJ004801), TaqMan Probe: 5'-FAM-AGG-ACC-GCG-AGT-TCT-TGC-CGC-TAMRA-3' (position 57525- 57545 GenBank®, accession AJ004801), with a target gene of 97 bp (Abril et al., 2004).

\section{Preparation of reaction mixtures}

All the reagents were mixed in a separate room before distribution to each individual reaction tube optical PCR/optical 96-well plate. Non-templates control (NTC, reagents only) and positive control (DNA BHV-1) were included in each test. PCR master mix was carried out in a final volume of $20 \mu \mathrm{L}$ containing $2 \mathrm{X}$ Sensifast Probe LoROX Mix (Bioscience) $10.0 \mu$, Forward Primer gBF $20 \mu \mathrm{M} 0.4 \mu 1$, Reverse Primer gBR $20 \mu \mathrm{M} 0.4 \mu 1$, Probe IBR 5 $\mu \mathrm{M} 0.4 \mu \mathrm{l}$, RNase Free Water $0.8 \mu \mathrm{l}$. The DNA template $8 \mu \mathrm{l}$ was added in the separate room. The PCR tubes were placed in the Real-time PCR detection system (ABI 7500, Applied Biosystems) with the following programme: 1 cycle of $50^{\circ} \mathrm{C}$ for 2 minutes, 1 cycle of $95^{\circ} \mathrm{C}$ for 5 minutes, 45 cycles of $95^{\circ} \mathrm{C}$ for 15 seconds, $60^{\circ} \mathrm{C}$ for 45 seconds. A threshold real-time PCR for BHV-1 setting up before determining the interpretation. Ct value were interpreted as positive $(\mathrm{Ct}<40)$, dubious $(40<\mathrm{Ct}<45)$, and negative $(\mathrm{CT}>45)$ (Abril et al., 2004).

\section{Data analysis}

The results of detection by real-time PCR were presented descriptively.

\section{RESULTS AND DISCUSSION}

The identification results of the BHV 1 virus in bull's semen are shown in Table 1. Based on the obtained results of qPCR examination, 27 semen samples from AI and Breeding Centers of Ungaran, Sleman, Sembawa, Lembang were negative. Therefore, the bull's semen from Ungaran, Sembawa, Sleman, and Lembang were safe sources of semen for AI. However, there is a need to carry out monitoring measures for these bulls. Although it is a good idea to perform serological tests every 6 months. In case of case positive in the cattle, the bull was stamped out. Screening strictly should be performed continuously in AI and Breeding Centers so that there would be no prevalence of IBR disease.

Table 1. Result of RT-PCR for detection of BHV-1 from semen of cattle located in four breeding area centers in Indonesia

\begin{tabular}{|c|c|c|c|c|}
\hline No & Sample Code & Area & Breed & Result of Real Time PCR \\
\hline 1 & Antoni 619157 & Lembang & Simental & - \\
\hline 2 & Gallant 618149 & Lembang & simental & - \\
\hline 3 & Girilaya 171921 & Lembang & Angus & - \\
\hline 4 & Puisgant 818135 & Lembang & Limosin & - \\
\hline 5 & Taureaux 818136 & Lembang & Limosin & - \\
\hline 6 & Bali 11510 & Sembawa & Bali & - \\
\hline 7 & Flores & Sembawa & Flores & - \\
\hline 8 & Simental 61821 & Sembawa & Simental & - \\
\hline 9 & Brahman 41613 & Sembawa & Brahman & - \\
\hline 10 & Brahman 41615 & Sembawa & Brahman & - \\
\hline 11 & Handsome 61359/s098 & Ungaran & Simental & - \\
\hline 12 & Sembara 61674/T.020 & Ungaran & Simental & - \\
\hline 13 & Umberto 80922/T035 & Ungaran & Limosin & - \\
\hline 14 & Kempo 20906/Q096 & Ungaran & $\mathrm{PO}$ & - \\
\hline 15 & Brahmana 41014/S100 & Ungaran & Brahman & - \\
\hline 16 & Benowo 141504/S098 & Ungaran & Brahman & - \\
\hline 17 & Asko & Sleman & Simental & - \\
\hline 18 & Limbada & Sleman & Limosin & - \\
\hline 19 & Orlando & Sleman & $\mathrm{PO}$ & - \\
\hline 20 & Eyser 6091HHO36A & Sleman & others & - \\
\hline 21 & Eyser 6091HHO36B & Sleman & others & - \\
\hline 22 & Satrio 61015GG060A & Sleman & others & - \\
\hline 23 & Satrio 61015GG060B & Sleman & others & - \\
\hline 24 & Suryo61013HH014A & Sleman & others & - \\
\hline 25 & Suryo61013HH014B & Sleman & others & - \\
\hline 26 & $\mathrm{C} 1$ & Sleman & others & - \\
\hline 27 & $\mathrm{C} 3$ & Sleman & others & - \\
\hline
\end{tabular}

- : negative 
The BHV-1 infection in cattle can cause several infectious pustular vulvovaginitis and infectious pustular balanoposthitis diseases. Infection in males can infect be transmitted to other cows even when there is no clinical symptom. Semen produced in and breeding centers must be seronegative for BHV-1 (Muylkens et al., 2007). The virus is secreted through nasal and eye secretions, placental fluid of aborted cattle, and semen (Rola et al., 2005). Regarding a study conducted on three bulls detected with BHV-1.5 in Brazil, it was found that BHV -1.5 was transmitted through nasal, ocular, genital contact (Henzel et al., 2019). The infectivity of BHV-1 remains stable during the storage of semen in liquid nitrogen. No decrease in titer was observed during storage for one year (4-12 months) following Chapman et al. (1979). Transmission of BHV1 can occur from contaminated sperm entering the oocyte during fertilization. The zona pellucida is an effective barrier to prevent the penetration of pathogens into the ovum (Bielanski, 2012).

Infected cattle do not always show clinical symptoms so they are not recognized as infected carrier cattle. The primary infection causes the virus to replicate itself in the nasal, vaginal, prepuce, and latent in the neural ganglia so that it can become a source of infection. Several immunosuppressive factors can trigger the virus for reactivation followed by viral excretion (Queiroz-Castro et al., 2018). Stress due to transport, weaning, and dietary changes are important triggering factors usually associated with virus reactivation (Raaperi et al., 2014). BHV1 can be transmitted directly or indirectly throughcontact with nasal, oral, and genital secretions. Other possible ways of transmission include primary respiratory, ocular, and sexual transmissions (Silva-Frade et al., 2014). Moreover, animals infected with BHV1become potential agents for the spread of the virus. The period of spread lasts up to day 11 post-infection.

The study described the low frequency of BHV-1 antigen in the semen of bulls in AI and breeding centers located in Indonesia. This is related to good management in the farm so it was possible to impact BHV-1 shedding and enhance the immune system. The study of Henzel et al. (2019) showed that two positive samples of BHV-1 PCR detection in bulls' semen in Brazil. Farms in Brazil have a history of nutritional and health management deficiencies, possibly favoring BHV-1 shedding in bull's semen. Saefulloh and Adjid (2010) reported that the presence of BHV-1 was detected 2.73\% (21 out of 770) by virus isolation while the nested PCR using gD primer gave positive results of $20.13 \%$ (155 out of 770) in nasal, vaginal swabs, and semen samples (Saefulloh and Adjid, 2010). The BHV 1 was detected in nasal swabs using Immuno Peroxidase Monolayer Assay (IPMA) in Breeding Centers Padang Mangatas, Indonesia (Untari et al., 2016).

\section{CONCLUSION}

The findings of the current study have indicated that there is no infection in the semen of bulls while going through Artificial Insemination in Breeding Centers of Indonesia using RT PCR detection. Regarding the obtained results, control and prevention must be put to prevent the prevalence of IBR in Indonesia, especially in AI and Breeding Centers.

\section{DECLARATIONS}

\section{Acknowledgments}

This research was carried out with the financial support of the Minister of Education and Culture, Indonesia scheme "Foundation Research" 2020, Government of Indonesia. We are grateful to all the facilitators for their support in sample collection and processing.

\section{Authors' contribution}

Tri Untari contribution to identification, Yuli PK contribution to sampling, handling the sample, and Asmarani Kusumawati to design, carry out the research, analyzed the data, and write the manuscript. The authors checked and confirm the final draft of the manuscript.

\section{Competing interests}

All authors declare no competing interests are to be reported.

\section{Ethical considerations}

Ethical issues (including plagiarism, consent to publish, misconduct, data fabrication and/or falsification, double publication and/or submission, and redundancy) have been checked by the authors before the submission.

\section{REFERENCES}

Abril C, Engels M, Liman A, Hilbe M, Albini S, Franchini M, Suter M, and Ackermann M (2004). Both viral and host factors contribute to neurovirulence of bovine herpesviruses 1 and 5 in interferon receptor-deficient mice. Journal of Virology, 78: 36443653. DOI: https://www.doi.org/10.1128/jvi.78.7.3644-3653.2004 
Anonim (2014). Law number 18 of 2009 concerning animal husbandry and health (PDF), Jakarta: State Secretariat. Available at: http://ditjenpkh.pertanian.go.id/userfiles/regulasi/85453cb4e07dc5422595300f5d9a890f.pdf

Bielanski A (2012). A review of the risk of contamination of semen and embryos during cryopreservation and measures to limit crosscontamination during banking to prevent disease transmission in ET practices. Theriogenology, 77(3): 467-482. DOI: https://www.doi.org/10.1016/j.theriogenology.2011.07.043

Chapman MS, Lucas MH, Hebert CN, and Goodey RG (1979). Survival of infectious bovine rhinotracheitis virus in stored bovine semen. Veterinary Science Communications, 3: 137-139. Available at: https://vdocuments.net/survival-of-infectious-bovinerhinotracheitis-virus-in-stored-bovine-semen.html

Henzel A, Salla PF, Mascitti AK, Demoliner M, Solyman MC, Lunge VR, and Spilki FR (2019). Bovine alphaherpesvirus 1 and 5 in semen from bulls presenting genital lesions under field conditions in Brazil. Arquivo Brasileiro de Medicina Veterinária e Zootecnia, 71(1): 197-203. DOI: https://www.doi.org/10.1590/1678-4162-10310

Muylkens B, Thiry J, Kirten P, Schynts F, and Thiry E (2007). Bovine herpesvirus 1 infection and infectious bovine rhinotracheitis. Veterinary Research, 38(2): 181-209. DOI: https://www.doi.org/10.1051/vetres:2006059

Oliviera MT, Campos FS, and Dias MM (2011). Detection of bovine herpesvirus 1 and 5 in 14 semen from Brazillian bulls. Theriogenology, 75: 1139-1145. DOI: https://www.doi.org/10.1016/j.theriogenology.2010.11.025

Queiroz-Castro VL, da Costa EP, and Alves SVP (2018). Detection of bovine herpesvirus-1 in cumulus-oocyte complexes of cows. Research in Veterinary Science, 120(1): 54-56. DOI: https://www.doi.org/10.1016/j.rvsc.2018.08.010

Rola J, Larska M, and Polak MP (2005). Detection of bovine herpesvirus-1 from an outbreak of infectious bovine rhinotracheitis. Bulletin-Veterinary Institute in Pulawy, 49: 267-271. Available at: http://citeseerx.ist.psu.edu

Raaperi K, Orro T, and Viltro PA (2014). Epidemiology and control of bovine herpesvirus 1 infection in Europe. The Veterinary Journal, 201: 249-256. DOI: https://www.doi.org/10.1016/j.tvjl.2014.05.040

Saefulloh M, and Adjid RMA (2010). Isolation and identification of bovine herpesvirus-1 from dairy and beef cattlein Indonesia. National Seminar of Husbandry and Veterinery, 6-7 October 2010, Bogor, Indonesia. Available at: https://docplayer.info/49566421-Isolasi-dan-identifikasi-bovine-herpesvirus-1-pada-sapi-perah-dan-potong-di-indonesia.html

Silva-Frade C, Gameiro R, and Okamura LH (2014). Programmed cell death associated gene transcripts in bovine embryosexposed to bovine herpesvirus type 5. Molecular and Cellular Probes, 28: 113-117. DOI: https://www.doi.org/10.1016/j.mcp.2013.10.005

Untari T, Purwandari YK, Kusumawati A, and Sutrisno B (2016). Detection of bovine herpes virus-1 in Indonesia by immunoperoxidase Monolayer Assay. Pakistan Veterinary Journal, 36(4): 506-507. Availablea at:http://www.pvj.com.pk/pdffiles/36_4/506-507.pdf 